\title{
BENTUK SAJIAN DAN FUNGSI LAGU ANAK DALAM PROSES TERAPI WICARA DI YAYASAN LOMBOK CARE
}

\author{
Yuga Anggana Sosani \\ Universitas Islam Negeri Mataram \\ yugaanggana@uinmataram.ac.id
}

\begin{abstract}
This study discusses the form and function of children's songs in process of speech therapy for children with Cerebral Palsy at the Lombokcare Foundation. The research method uses descriptive qualitative type, aims to determine how the presence of children's songs of speech therapy for children with Cerebral Palsy, and what is the function of children's songs in the rehabilitation process for children with disabilities. Data collection was carried out by observation, interviews, document study in the form of audio recordings, and video taking. The results showed that children's songs used for therapy for children with disabilities have a simple, short, and easy to remember melody for children. The theme of the song tells about things that exist in a child's daily life. In general, the song text contains educational value as a means of making it easier for children to learn, the rhythm of the song responds children to actively move, the song melody uses a tone range of no more than one octave to make it easier for children to reach the sound. Children's songs function as a means of entertainment, physical reaction stimulus, learning support media, and conducive atmosphere in the speech therapy process.
\end{abstract}

Keywords: Cerebral Palsy, Disabilities, Children's Songs, Speech Therapy

\begin{abstract}
Abstrak
Tulisan ini membahas tentang bentuk sajian dan fungsi lagu anak dalam proses terapi wicara pada anak penyandang Cerebral Palsy di Yayasan Lombokcare. Penelitian menggunakan metode deskriptif kualitatif, untuk mengetahui bagaimana bentuk sajian lagu anak untuk keperluan terapi wicara pada anak penyandang Cerebral Palsy, serta apa fungsi lagu anak pada proses rehabilitasi anak penyandang disabilitas. Pengumpulan data dilakukan dengan observasi, wawancara, studi dokumen berupa rekaman audio dan pengambilan video. Hasil penelitian menunjukkan bahwa lagu anak yang digunakan untuk terapi anak penyandang disabilitas memiliki karakter melodi lagu yang sederhana, singkat, dan mudah diingat oleh anak-anak, tema lagu bercerita tentang hal-hal yang terdapat dalam keseharian anak. Secara umum teks lagu mengandung nilai pendidikan sebagai sarana mempermudah anak untuk belajar, irama lagu mengajak anak untuk aktif bergerak, melodi lagu menggunakan rentang nada tidak lebih dari satu oktaf agar memudahkan anak menjangkau jarak suara. Lagu anak berfungsi sebagai penghibur bagi anak, juga sebagai stimulus reaksi jasmani dalam proses terapi, sebagai media pendukung pembelajaran dalam terapi wicara dan berfungsi untuk membangun suasana yang kondusif dalam proses terapi wicara.
\end{abstract}

Kata Kunci: Cerebral Palsy, Disabilitas, Lagu Anak, Terapi Wicara 


\section{PENDAHULUAN}

Disabilitas atau kecacatan banyak dialami oleh sebagian masyarakat, baik kecacatan yang dialami dari lahir maupun karena kecelakaan yang mengakibatkan seseorang menjadi cacat. Kondisi yang tidak sempurna membuat penyandang disabilitas memiliki keterbatasan dan hambatan dalam menjalani kehidupan dan memenuhi kebutuhannya. Di Indonesia, pemerintah mempunyai keseriusan dalam menangani atau memberikan layanan sosial kepada penyandang disabilitas, suatu upaya yang dilakukan adalah melalui panti sosial, sebagai lembaga pelayanan kesejahteraan sosial yang memiliki tugas dan fungsi untuk meningkatkan kualitas sumber daya manusia dan memperdayakan penyandang masalah kesejahteraan kearah kehidupan normatif secara fisik, mental dan sosial. Oleh sebab itu pelayanan melalui sistem panti pada hakikatnya merupakan upaya-upaya yang bersifat pencegahan, penyembuhan, terapi dan rehabilitasi, serta pengembangan potensi bagi individu penyandang disabilitas, menjadi penting peranannya. Panti sosial dapat digunakan sebagai pusat kesehatan sosial yang berada di baris paling depan dalam melaksanakan tugas dan fungsi penyelenggaraan kesejahteraan sosial dan pilar intervensi pelayanan dan rehabilitasi sosial.

Selain panti sosial di bawah pemerintahan kini banyak terdapat lembaga swadaya masyarakat yang juga bergerak pada layanan sosial untuk penyandang disabilitas. Lombokcare, salah satu yayasan sosial di Kabupaten Lombok Barat untuk anak penyandang disabilitas adalah yayasan yang mulai aktif sejak tahun 2010 melakukan pelayanan terapi dan rehabilitasi (fisioterapi anak, terapi wicara, okupasi terapi dan sensori integrasi) dan pelayanan edukasi (Sekolah Luar Biasa dan Life Skills).

Dalam melaksanakan pelayanan terapi dan edukasi anak penyandang disabilitas Yayasan Lombokcare menerapkan metode yang berbeda dari panti terapi lainnya. Metode yang digunakan ialah dengan melakukan pendekatan seni, yaitu penggunaan lagu anak dalam proses terapi. Penggunaan lagu anak tersebut digunakan untuk terapi wicara, khususnya bagi anak dengan gangguan cerebral palsy. Lagu anak yang digunakan dalam proses terapi wicara adalah lagu anak yang diciptakan langsung oleh ketua yayasan, yang sengaja dibuat khusus untuk kebutuhan rehabilitasi dan edukasi.

Terapi dan rehabilitasi berarti pemulihan, dalam kaitannya dengan disabilitas terapi dan rehabilitasi berarti pengembalian para penyandang disabilitas kepada 
kegunaan secara maksimal baik dalam aspek fisik, mental, personal, sosial, vocational, serta ekonomi sesuai dengan kemampuannya. Secara umum tahapan terapi dan rehabilitasi pada anak penyandang disabilitas yaitu: (1) Pendekatan Awal (2) Tahap Orientasi (3) Asesmen (4) Temu Bahas Kasus (Case Conference) (5) Pelaksanaan Rehabilitas Sosial dan (6) bimbingan lanjutan. Namun pada penanganan terapi dan rehabilitasi anak penyandang disabilitas tahapan-tahapan tersebut disesuaikan dengan kondisi anak, penyesuaian umur dan tumbuh kembang anak yang hendak di terapi. Kendala yang sering dialami oleh terapis dan anak penyandang disabilitas pada saat proses terapi di antaranya; mengalamai suasana kebosanan dengan metode rehabilitasi yang cenderung monoton. Suasana bosan menjadikan terapis dan anak penyandang disabiltas kehilangan fokus saat menjalani proses terapi. Hal tersebut menjadikan proses terapi menjadi kurang efektif.

Terapi seni merupakan terapi yang menggunakan medium seni seperti musik, tari, lukis, seni rupa, dan lain-lain yang ditujukan untuk memberikan aktivitas yang menyenangkan, memberikan kepuasan dan meningkatkan harga diri, kepercayaan diri serta meningkatkan interaksi sosial penyandang disabilitas. Kegiatan ini ditujukan pula untuk meningkatkan keterampilan interaksi sosial dari penerima manfaat. Terapi seni dilakukan melalui kegiatan seni melukis dan musik yang diberikan dua kali seminggu di bawah bimbingan instruktur, sekali untuk bimbingan keterampilan melukis dan sekali untuk bimbingan keterampilan musik.

Musik merupakan kebutuhan manusia secara universal yang tidak pernah berdiri sendiri lepas dari masyarakat (Boedhisantoso, 1982). Bernstein \& Picker (1972) mengatakan bahwa musik adalah suara-suara yang diorganisasikan dalam waktu dan memiliki nilai seni dan dapat digunakan sebagai alat untuk mengekspresikan ide dan emosi dari komposer kepada pendengarnya. Gallahue, (1998) mengatakan, kemampuan-kemampuan seperti sinkronis, ritme, visual, urutan dalam pergerakan, makin dioptimalkan melalui stimulasi dengan memperdengarkan musik klasik. Kemampuan belajar anak dapat ditingkatkan dengan stimulasi dari ketukan, melodi, dan harmoni dari musik klasik. Melalui musik, anak mudah menangkap hubungan antara waktu, jarak dan urutan (rangkaian) yang merupakan keterampilan yang dibutuhkan untuk kecakapan dalam logika berpikir. Musik berhasil merangsang pola pikir dan menjadi jembatan bagi pemikiran-pemikiran yang lebih kompleks. Penelitian Martin Gardner (1996) dalam Goleman (1995) mengatakan seni dan musik dapat 
membuat anak lebih pintar, musik dapat membantu otak berfokus pada hal lain yang dipelajari. Jadi, ada hubungan logis antara musik dan matematika, karena keduanya menyangkut skala yang naik turun, yaitu ketukan dalam musik dan angka dalam matematika. Daryono Sutoyo(1981), Guru Besar Biologi UNS Solo, melakukan penelitian tentang kontribusi musik yaitu menstimulasi otak, mengatakan bahwa pendidikan kesenian penting diajarkan mulai dari tingkat anak usia dini agar peserta didik sejak dini memperoleh stimulasi yang seimbang antara belahan otak kiri dan belahan otak kanannya. Bila mereka mampu menggunakan fungsi kedua belahan otaknya secara seimbang, maka apabila mereka dewasa akan menjadi manusia yang berpikir logis dan intutif, sekaligus cerdas, kreatif, jujur, dan tajam perasaannya.

Secara umum yang dimaksud dengan lagu anak adalah lagu untuk dinyanyikan oleh anak, dan atau lagu yang dinyanyikan untuk anak. Lagu anak-anak adalah lagu yang dirancang sedemikian rupa, baik lirik maupun melodinya sesuai dengan karakteristik dan kebutuhan anak. Melodi lagu anak umumnya bertempo sedang dan kaya pengulangan. Sementara liriknya disusun dengan bahasa yang sederhana, mudah diucapkan, dan kaya pengulangan. Dalam kaitannya dengan analisa lagu, Edmund Prier mengatakan bahwa lagu perlu dibedah dan memperhatikan setiap elemen, struktur dan bagian-bagian secara detail, di antaranya: tema alur melodi, bentuk dan struktur lagu, birama, tempo hingga kesan dan pesan dari lagu tersebut.

Secara fungsi, lagu anak (musik) berfungsi (1) memberikan kenikmatan estetis. Musik merupakan suatu karya seni. Suatu karya dapat dikatakan karya seni apabila dia memiliki unsur keindahan atau estetika di dalamnya. Melalui musik kita dapat merasakan nilai-nilai keindahan baik melalui melodi atupun dinamikanya. (2) memberikan relaksasi atau hiburan. Musik memiliki fungsi hiburan mengacu kepada pengertian bahwa sebuah musik pasti mengandung unsur-unsur yang bersifat menghibur. Hal ini dapat dinilai dari melodi ataupun liriknya. (3) sebagai media ekspresi diri. Dalam hal ini musik berfungsi sebagai suatu media bagi seseorang untuk mengungkapkan perasaan atau emosinya, dengan kata lain pemain musik dapat mengungkapkan perasaan atau emosinya melalui musik. (4) sebagai media komunikasi. Musik memiliki fungsi komunikasi berarti bahwa sebuah musik yang berlaku di suatu daerah kebudayaan mengandung isyarat-isyarat tersendiri yang hanya diketahui oleh masyarakat pendukung kebudayaan tersebut. Hal ini dapat dilihat dari teks atau pun melodi musik tersebut. (7) sebagai sarana pemersatu masyarakat. Musik memiliki 
fungsi dalam pengintegrasian masyarakat. Suatu musik jika dimainkan secara bersamasama maka tanpa disadari musik tersebut menimbulkan rasa kebersamaan diantara pemain atau penikmat musik itu. (8) menguatkan konformitas terhadap norma sosial. Musik berfungsi sebagai media pengajaran akan norma-norma atau peraturanperaturan. Penyampaian kebanyakan melalui teks-teks nyanyian yang berisi aturanaturan. (9) memvalidasi institusi-institusi sosial dan ritual keagamaan. Fungsi musik disini berarti bahwa sebuah musik memiliki peranan yang sangat penting dalam suatu upacara. Musik merupakan salah satu unsur yang penting dan menjadi bagian dalam upacara, bukan hanya sebagai pengiring. (10) sebagai media pendidikan serta pembelajaran. Fungsi ini hampir sama dengan fungsi yang berkaitan dengan norma sosial, dalam hal ini musik berisi tentang ajaran-ajaran untuk meneruskan sebuah sistem dalam kebudayaan terhadap generasi selanjutnya (Budhisantoso 1994; Merriam, 1968; dan Merrit, 2003). Selain ke-sepuluh fungsi tersebut di atas, dari sisi psikologis musik bisa berfungsi sebagai media terapi.

Terapi wicara (speech therapy) merupakan suatu proses pengobatan pada penderita gangguan perilaku komunikasi sehingga penderita gangguan perilaku komunikasi mampu berinteraksi dengan lingkungan secara wajar tidak mengalami gangguan psikososial serta mampu meningkatkan hidup optimal. Cerebral palsy merupakan brain injury yaitu suatu kondisi yang mempengaruhi pengendalian sistem motorik sebagai akibat lesi dalam otak, atau suatu penyakit neuromuskuler yang disebabkan oleh gangguan perkembangan atau kerusakan sebagian dari otak yang berhubungan dengan pengendalian fungsi motorik. Kemampuan berbahasa merupakan kemampuan dalam menggunakan simbol-simbol verbal atau nonverbal dari konsep atau pengertian yang digunakan oleh lingkungannya. Saat ini terapi wicara menjadi sebuah pilihan untuk menstimulasi perkembangan berbahasa pada anak cerebral palsy dan bisa dikatakan aktivitas wicara mempunyai andil dalam kesuksesan ini, kontribusinya sangat bernilai dalam berkomunikasi dengan lingkungannya, dalam meluapkan perasaan, fikiran serta ide-idenya. Sehingga peneliti tertarik untuk meneliti efektivitas terapi wicara untuk meningkatkan kemampuan berbahasa pada anak yang memiliki gangguan cerebral palsy.

Musik dan lagu menurut penelitian terdahulu sudah terbukti menjadi metode terapi bagi orang dewasa maupun anak-anak. (Geretsegger, Elefant, Mössler, \& Gold, 2014; Reschke-Hernández, 2011; Yinger \& Gooding, 2014). Penelitian lain juga 
menunjukkan efektifitas terapi lagu dan music khusus bagi penderita cerebral palsy (Kwak, 2007; Rainey Perry, 2003; Yu, Liu, Li, \& Ma, 2009) Penelitian ini memberikan pengayaan dari penelitian terdahulu dengan dua permasalahan sebagai berikut: bagaimana bentuk sajian lagu anak dalam proses terapi wicara pada anak penyandang cerebral palsy? dan apa fungsi lagu anak pada proses dalam proses terapi wicara pada anak penyandang cerebral palsy?

\section{METODE}

Jenis penelitian ini adalah penelitian kualitatif. Data yang dikumpulkan dalam penelitian kualitatif berupa kata-kata, gambar dan bukan angka-angka. Penelitian kualitatif bermaksud untuk memahami fenomena tentang persepsi, motivasi, tindakan dan lain-lain secara holistik dan dengan cara deskripsi dalam bentuk kata-kata dan bahasa, pada suatu konteks khusus yang alamiah dan dengan memanfaatkan metode ilmiah (Moleong, 2011).

Metode yang digunakan dalam penelitian ini adalah metode deskriptif kualitatif. Metode tersebut digunakan untuk mengetahui bagaimana bentuk dan peran lagu anak dalam proses terapi wicara pada anak penyandang cerebral palsy di Yayasan Lombok Care. Dengan demikian untuk memperoleh data, penulis melakukan kegiatan observasi dan pengamatan secara langsung di Yayasan Lombok Care. Pengamatan dilakukan pada saat terapis melakukan proses terapi pada anak penyandang Cerebral Palsy. Selain observasi dan pengamatan, wawancara dilakukan terhadap Ketua Yayasan Lombok Care sebagai orang yang membuat lagu anak untuk keperluan terapi wicara. Teknik lainnya dalam pengambilan data dilakukan dengan cara pengambilan gambar dan video, serta studi dokumen berupa rekaman lagu dan teks lagu anak berjudul Belajar Suara Binatang yang merupakan lagu untuk keperluan terapi wicara. Rekaman audio dan teks lagu tersebut digunakan untuk mendeskripsikan proses kreatif, bentuk penyajian lagu anak dan peran lagu anak dalam proses terapi wicara.

\section{HASIL PENELITIAN DAN PEMBAHASAN}

\section{Lagu Anak}

Secara umum yang dimaksud dengan lagu anak adalah lagu yang dinyanyikan oleh anak atau lagu yang dinyanyikan untuk anak. Lagu anak memiliki karakteristik melodi yang mudah diingat oleh anak dan tetap mudah untuk dinyanyikan meskipun 
tanpa teks berbahasa. Irama lagu anak biasanya menarik perhatian anak, dengan teks lagu yang memiliki kerangka irama yang sama dengan irama lagu. Teks pada lagu anak sesuai dengan garis melodi musiknya. Begitupun pesan dan rasa teks sesuai dengan pesan dan rasa musiknya.

Tema dalam lagu anak mengandung pesan moral yang berguna bagi perkembangan karakter anak, juga mengandung nilai-nilai pendidikan misalnya tentang kebaikan, persahabatan dan lainnya. Dalam hal ini lagu anak berfungsi sebagai sarana pendidikan. Lagu anak juga berfungsi sebagai sarana komunikasi, misalnya ketika seorang ibu menyanyikan lagu Nina Bobo di setiap kai anak akan tidur akan membuat si anak paham sudah waktunya untuk naik ke tempat tidur. Contoh lainnya, lagu anak berjudul Bangun Tidur ciptaan Pak Kasur mengajarkan anak untuk dispilin, karena lagu anak menyampaikan pesan lebih baik dibanding hanya sekedar perintah atau nasehat secara langsung.

Lagu anak memiliki struktur yang berulang dengan teks yang sederhana dan tidak terlalu panjang. Kalaupun teks lagu anak lebih dari tiga bait biasanya teks mengandung cerita yang menyenangkan. Beberapa lagu anak bersifat atraktif dan interaktif, artinya mengajak anak untuk bergerak dan mengikuti irama juga teks lagu anak.

Bentuk sajian lagu anak adalah sajian sederhana. Rentang nada yang digunakan tidak lebih dari satu oktaf - 1 (do) rendah ke i (do) tinggi - dengan wilayah nada yang sesuai dengan range suara anak. Dalam lagu anak terdapat nada-nada dominan yaitu 1 (do), 3 (mi) dan 5 (sol). Hampir semua lagu anak di Indonesia menggunakan nada dominan, lagu dimulai dengan nada 1 (do), 3 (mi) atau 5 (sol) dan diakhiri dengan nada 1 (do).

- Contoh notasi angka pada lagu Burung Kakak Tua :

..5|5.3|i.3|2..|..4|4.6|5.4|3..|.5|5.3|i.3|2 ..|..1|7.5|6.7| i.. $. .5|3.5| 3.5|666| 6.4|2.4| 2.4|555| 5.5|3.5| 3.5|666| 2 . i$ | 7.5|6.7|i...

- Contoh notasi angka pada lagu Naik-naik ke puncak gunung $. .5|1.1| 1.2|333| 1.3|2.1| 712|1 .| ..5|1.1| 1.2|333| 1.3 \mid 2.1$ |712|1..|..5|6.6|4.6|555|3.5|5.4|234|3.4|5.5|6.6|4.6|5 $55|3.5| 5.4|232| 1 .$. 
Contoh notasi angka pada dua lagu anak di atas menunjukan lagu anak dimulai dengan nada 5 (sol) dan berakhir pada nada 1 (do).

Sekarang mari kita simak notasi angka lagu anak yang dibuat oleh Yayasan Lombok Care, yang ditujukan khusus untuk keperluan terapi wicara, berjudul Belajar Suara Binatang.

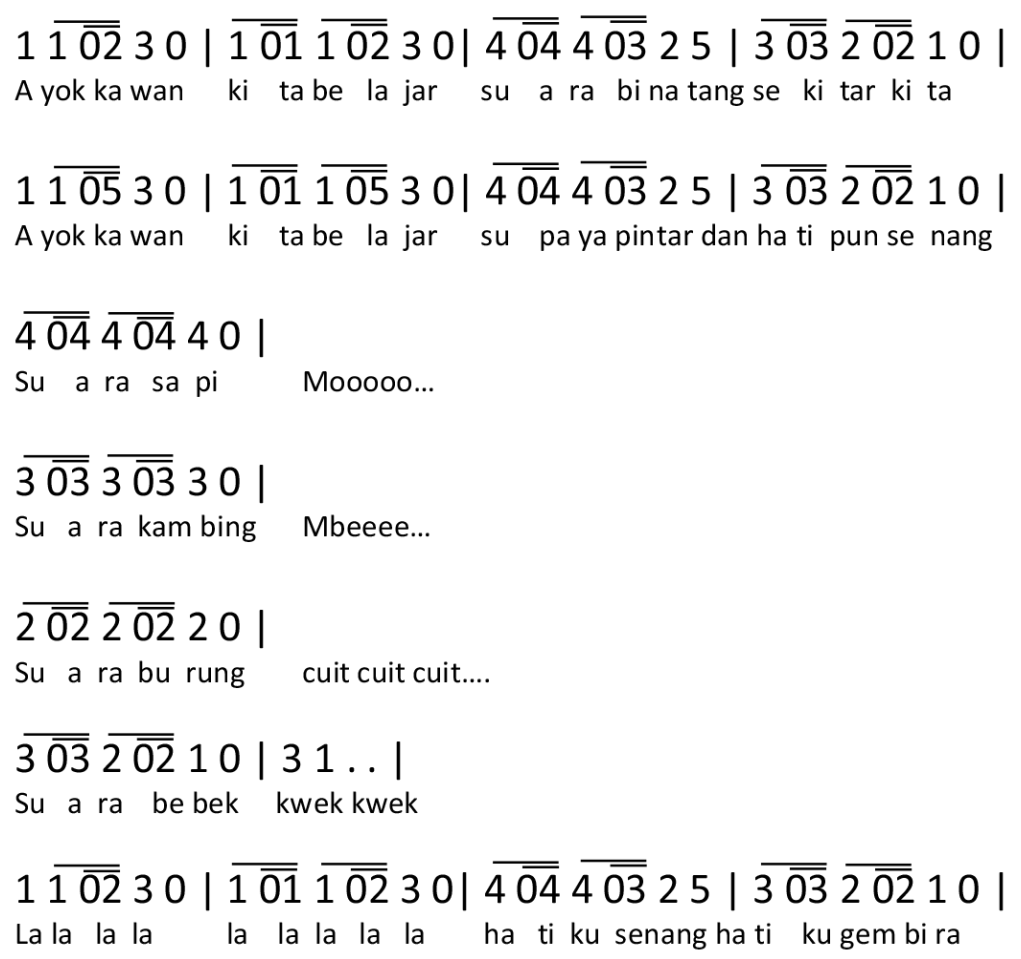

Lagu Belajar Suara Binatang dimulai dengan nada 1 (do) dan di akhiri dengan nada yang sama, 1 (do). Lagu ini menggunakan tempo Andante, sebutan bagi tempo yang cepat, riang seperti orang berjalan.

Belajar Suara Binatang merupakan lagu anak yang memiliki dua tema, tema A dan B. Berikut penjelasannya:

Tema A:

$1 \overline{1 \overline{02}} 30$ 0| $\overline{1 \overline{01}} \overline{1 \overline{02}} 3$ 이 $\overline{4 \overline{04}} \overline{4 \overline{03}} 25 \mid \overline{3 \overline{03}} \overline{2 \overline{02}} 10$ |

Tema B:

$\overline{4 \overline{04}} \overline{4 \overline{04}} 40|\overline{3 \overline{03}} \overline{3 \overline{03}} 30| \overline{2 \overline{02}} \overline{2 \overline{02}} 20 \mid$

$\overline{3 \overline{03}} \overline{2 \overline{02}} 10|31 \ldots|$

Maka jika kita analisa berdasarkan tema di atas beserta teks lagu yang digunakan, lagu Belajar Suara Binatang memiliki struktur lagu sebagai berikut:

1. Intro 
2. Tema A (1):

Ayo kawan kita belajar suara binatang sekitar kita

Ayo kawan kita belajar supaya pintar dan hati pun senang

3. Tema B:

Suara sapi, mooo

Suara kambing, mbeee

Suara burung, cuit cuit cuit

Suara bebek, kwek kwek

4. Tema A (2):

Lalalala lalalalala hatiku senang hatiku gembira

Lalalala lalalalala hatiku senang hatiku gembira

5. Interlude

6. Tema A (1 - teks berbeda):

Ayo kawan kita belajar suara binatang di sekitar kita

Ayo kawan kita belajar supaya pintar dan hari pun senang

7. Tema B (teks berbeda):

Suara tokek tokek

Suara anjing guk guk guk

Suara kucing meong

Suara ayam kukuruyuk

8. Outro

Simpulan struktur lagu Belajar Suara Binantang: Intro - Tema A - Tema B -

Tema A - Interlude - Tema A - Tema B - Outro

Lagu Belajar Suara Binatang disajikan dengan irama riang (vivace) dengan tempo Andante seperti orang berjalan. Teks lagu Belajar Suara Binatang mengajak pendengarnya untuk turut meniru suara binatang seperti pada kata "Suara sapi, Moooo. Suara Kambing, "Mbeeee” dan lain sebagainya. Dengan irama musik yang riang dan teks lagu mengajak pendengar bernyanyi, lagu Belajar Suara Binatang yang ditujukan untuk keperluan terapi wicara pada anak pengidap Cerebral Palsy adalah lagu yang memiliki rasa musikal yang atraktif dan interaktif.

Dari sampel lagu anak yang digunakan sebagai media terapi di Yayasan Lombok Care, kedua lagu tersebut memiliki karakter melodi lagu yang sederhana, singkat, dan mudah diingat oleh anak-anak, tema lagu bercerita tentang hal-hal yang terdapat dalam 
keseharian anak. Secara umum teks lagu mengandung nilai pendidikan sebagai sarana mempermudah anak untuk belajar, irama lagu mengajak anak untuk aktif bergerak, melodi lagu menggunakan rentang nada tidak lebih dari satu oktaf agar memudahkan anak menjangkau jarak suara.

\section{Peran dan Fungsi Lagu Anak Pada Terapi Wicara}

Pada dasarnya bicara merupakan suatu perilaku manusia sebagai hasil aktivitas psikis yang diungkapkan melalui aktivitas fisik. Dengan kata lain bicara adalah proses psiko-fisik. Mekanisme bicara hanya akan terjadi apabila terdapat fungsi psikis dan fungsi fisik yang normal. Bila terdapat gangguan pada salah satu fungsi tersebut maka tidak akan terjadi mekanisme bicara yang baik. Kelainan Bahasa dan bicara yang digolongkan sebagai kelainan perilaku komunikasi, terjadi akibat adanya penyakit, gangguan atau kelainan fisik, psikis, sosiologis. Kelainan gangguan atau penyakit tersebut dapat timbul pada masa sebelum lahir, saat lahir, dan pada masa setelah lahir. Kelainan bicara adalah salah atu jenis kelainan perilaku komunikasi yang ditandai dengan adanya kesalahan dalam proses produksi bunyi bicara. Kesalahan proses produksi bunyi saat bicara tersebut menyebabkan kesalahan artikulasi fonem, baik dalam segi penempatan artikulasi dan dalam segi cara pengucapan. Ada banyak penyebab dan jenis kelainan bicara, Lombok Care mendata rata-rata penyebab kelainan bicara disebabkan oleh kondisi fisik yaitu Cerebral Palsy, sebuah gangguan motorik yang di sebabkan oleh kerusakan yang tidak progresif pada perkembangan otak.

Tindakan-tindakan yang dilakukan dalam terapi wicara di Yayasan Lombok menggunakan prosedur secara umum, mulai dari pengkajian yaitu paroses yang dilakukan untuk mengetahui gejala gangguan atau kelainan perilkau komunikasi secara sistemastis, baik gejala subyektif atau gejala obyektif. Pengkajian dilakukan melalui metode wawancara, observasi, tes khusus untuk mengukur kemampuan komunikasi. Tindakan selanjutnya adalah diagnostic dan prognostic yaitu memperkirakan perkembangan optimal yang dapat atau mungkin dicapai oleh penderita. Setelah tahapan pengkajian dan diagnostic prognostic maka dilakukan perencanaan untuk menyusun langkah-langkah kegiatan untuk mencapai tujuan terapi wicara.

Pelaksanaan terapi wicara dilakukan bertahap. Di antaranya: (1) Stimulasi, memberikan rangsangan yang cukup kuat sehingga dapat diterima dengan lebih mudah. Rangsangan yang diberikan dapat berupa rangsangan visual, auditorius, dan taktil. (2) 
Psikoedukasi, dilakukan dengan memberikan pengertian-pengertian positif untuk memotivasi penderita menjadi lebih optimis (3) Motokinestetik, melatih penderita agar mampu menempatkan organ atau otot dengan benar (4) Penempatan Fonetik, melatih penderita agar mampu menempatkan organ bicara pada tempat yang tepat dan menggerakkan dengan cara yang benar sehingga dapat mengucapkan bunyi Bahasa yang benar (6) evaluasi, dilakukan untuk mengetahui perkembangan kemampuan yang telah diterapi.

Pada proses stimulasi dan psikoedukasi, lagu anak digunakan untuk membangun suasana yang lebih positif. Pada proses stimulasi dan psikoedukasi pengaruh mendengarkan lagu lebih besar terhadap suasana hati daripada menonton video. Lagu dengan kategori riang gembira menghasilkan peningkatan suasana hati yang positif. Lagu anak memberi efek meningkatkan konsentrasi, sehingga pada proses terapi penderita akan lebih mudah memberi perhatian pada terapis. Dalam tahap stimulasi dan psikoedukasi ini lagu anak juga digunakan untuk menumbuhkan hubungan saling percaya antara terapis dan penderita.

Lagu anak pada tahapan motokinestetik berperan sebagai media perangsang reaksi jasmani. Irama dan tempo lagu anak menjadi iringan yang menstimulus pendengar untuk bergerak dan mengikuti nyanyian menggerakan rongga-rongga mulutnya. Contohnya pada lagu Belajar Suara Binatang kalimat Lalalala pada teks lagu melatih penderita untuk membuka mulut dan menaik turunkan lidah untuk membentuk kata 'la'. Begitupun pada bagian teks lainnya di lagu tersebut, seperti kata 'mooooo', 'mbeeeeee', 'cuit cuit' dan kata 'kwek kwek'.

Tahapan penempatan fonetik dilakukan untuk melatih dan mengembangkan artikulasi pada proses terapi wicara. Teks lagu anak Belajar Suara Binatang juga berkontribusi menjadi media latihan penempatan fonetik - pembentukan unsur Bahasa, perbendaharaan Bahasa, vokalisasi refleksif, babbling, lalling, ekolia hingga bicara benar, fokus kegiatan penempatan fonetik ialah melatih pelafalan huruf vokal dan konsonan, yaitu:

1. $a, i, u, e, o$

2. $p, b, m, w, y, n g, n y, d, h$

3. $t, n, k, g, s, f$

4. l, j, c, sy

5. $\mathrm{r}, \mathrm{kh}$ 
Mengacu pada penyesuaian lagu anak terhadap proses terapi wicara di atas maka lagu anak di Yayasan Lombok Care memiliki beberapa fungsi. Lagu anak dijadikan sebagai media hiburan yang berfungsi untuk membangun suasana yang positif, riang gembira, ceria dan optimis. Lagu anak dari Yayasan Lombok Care dibuat menjadi lagu yang interaktif yang mampu membangun dialog antara terapis dengan penderita, dalam hal ini lagu menjadi media komunikasi antara terapis dan penderita. Pengenalan nama dan suara binatang menjadi salah satu cara mengedukasi anak-anak di Yayasan Lombok Care terhadap hewan-hewan di lingkungan sekitar mereka, maka lagu anak difungsikan menjadi media pendidikan pengenalan alam sekitar. Irama lagu anak yang riang gembira menstimulus pendengar untuk bergerak mengikuti irama dan bernyanyi sesuai teks lagu yang mudah diingat. Lagu anak berfungsi sebagai stimulus reaksi jasmani. Lalu kemudian lagu anak dari Yayasan Lombok Care melatih dan mengembangakan fonetik dan gerak mulut pada proses terapi wicara menjadikan lagu tersebut berpesan sebagai media terapi wicara.

Selain peran dan fungsi lagu anak pada proses terapi wicara, Yayasan Lombok Care menggunakan lagu anak sebagai bagian dari keseharian pada waktu-waktu tertentu. Lagu anak dalam proses rehabilitasi dan terapi lainnya dianggap mampu menjadi media terapi baik dalam hal perkembangan fisik juga membangun suasana psikis menjadi lebih positif.

\section{KESIMPULAN}

Lagu anak dari Yayasan Lombok Care diciptakan khusus untuk keperluan terapi wicara, lagu anak tersebut merupakan lagu yang bisa dinyakian oleh orang dewasa untuk anak-anak juga bisa dinyanyikan oleh anak-anak karena range suara bisa dijangkau oleh orang dewasa dan anak-anak. Salah satu lagu anak dari Yayasan Lombok Care berjudul Belajar Suara Binatang memiliki karakteristik melodi yang mudah diingat oleh anak dan tetap mudah untuk dinyanyikan meskipun tanpa teks. Irama lagunya menarik perhatian anak, dengan teks lagu yang memiliki kerangka irama yang sama dengan irama lagu. Teks pada lagu sesuai dengan garis melodi musiknya. Begitupun pesan dan rasa teks sesuai dengan pesan dan rasa musiknya. Tema dalam lagu anak Belajar Suara Binatang mengandung nilai-nilai edukatif yaitu mengenalkan anak pada lingkungan sekitar - jenis dan suara binatang, juga mengajak anak-anak untuk berinteraksi menirukan suara-suara binatang. Lagu anak Belajar Suara Binatang 
memiliki struktur yang berulang dengan teks yang sederhana dan tidak terlalu panjang. Lagu anak Belajar Suara Binatang dimulai dengan nada 1 (do) dan di akhiri dengan nada yang sama, 1 (do). Lagu ini menggunakan tempo Andante, sebutan bagi tempo yang cepat, riang seperti orang berjalan. Belajar Suara Binatang merupakan lagu anak yang memiliki dua tema, tema A dan B. Simpulan struktur lagu Belajar Suara Binantang: Intro - Tema A - Tema B - Tema A - Interlude - Tema A - Tema B - Outro.

Lagu Belajar Suara Binatang disajikan dengan irama riang (vivace) dengan tempo Andante seperti orang berjalan. Teks lagu Belajar Suara Binatang mengajak pendengarnya untuk turut meniru suara binatang seperti pada kata "Suara sapi, Moooo. Suara Kambing, "Mbeeee" dan lain sebagainya. Dengan irama musik yang riang dan teks lagu mengajak pendengar bernyanyi, lagu Belajar Suara Binatang yang ditujukan untuk keperluan terapi wicara pada anak pengidap Cerebral Palsy adalah lagu yang memiliki rasa musikal yang atraktif dan interaktif.

Lagu anak di Yayasan Lombok Care berfungsi sebagai media hiburan, fungsi komunikasi, fungsi pendidikan, dan berfungsi sebagai stimulus gerak jasmani. Sebagai lagu yang diperuntukkan bagi terapi, lagu anak dari Yayasan Lombok menjadi memiliki fungsi utama sebagai media untuk melatih dan mengembangakan fonetik dan gerak mulut pada proses terapi wicara.

\section{SARAN}

Tidak banyak panti rehabilitasi dan terapi yang menggunakan media seni dalam proses terapi dan rehabilitasinya, Lombok Care menjadi salah satu Yayasan yang berinovasi menjadikan media seni sebagai instrumen pada proses terapi wicara. Lagu anak yang digarap oleh Yayasan Lombok berpotensi menjadi model dalam penerapan musik sebagai terapi. Maka perlu adanya pengembangan-pengembangan lebih jauh seperti misalnya pembuatan video khusus bagaimana mengaplikasikan lagu anak tersebut pada proses rehabilitasi dan terapi. Selain itu rumusan bentuk sajian dan struktur lagu anak dari Yayasan Lombok Care harus menjadi kunci untuk pembuatan lagu-lagu atau musik-musik lainnya agar inventaris lagu anak untuk terpai menjadi semakin beragam. Harapannya dengan pengembangan dan upaya memperbanyak lagu anak khusus terapi tersebut menjadi konsep baru dalam mempercepat proses rehabilitasi dan terapi mencapai tujuan yang diinginkan. 


\section{DAFTAR PUSATAKA}

Alan P. Merriam. (1964). The Anthropology of Music. Chicago: Northwestern University Press.

Bambang Setyono, SpTh. (2000). Terapi Wicara Untuk Praktisi Pendidikan dan Kesehatan. Jakarta:

Bernstein, M. , \& Picker. M., (2001). An Introduction to Music. New. Jersey: Prentice Hall, Inc, Eaglewood Cliffs. Campbel, D.

Boedhisantoso, S., (1982). Kesenian Dan Nilai-Nilai Budaya. Jakarta: Depdikbud.

Djohan. (2009). Psikologi Musik, Yogyakarta: Penerbit Best Publisher.

Djohan. (2006). Terapi Musik: Teori dan Aplikasi. Yogyakarta: Galang Press.

Freeman Miller, MD. (2004). Cerebral Palsy. USA.

Gallahue, D.L., Ozmun, J.C. (1998). Understanding Motor Development: Infants, Children, Adolescence, Adults. 4 Edition. New York: McGraw Hill, Inc.

Geretsegger, M., Elefant, C., Mössler, K. A., \& Gold, C. (2014). Music therapy for people with autism spectrum disorder. Cochrane Database of Systematic Reviews. https://doi.org/10.1002/14651858.CD004381.pub3.

Ismawati Dan Rima Vien Permata Hartanto. (2018). Pelaksanaan Rehabilitasi Sosial Bagi Penyandang Disabilitas Daksa Dalam Meningkatkan Akses Pekerjaan, Jurnal Sosio Informa, 4(3), September - Desember.

Karl Edmund Prier SJ. (2017). Ilmu Bentuk Musik. Yogyakarta: Pusat Musik Liturgis.

Karl Edmund Prier SJ. (2014). Kamus Musik. Yogyakarta: Pusat Musik Liturgis.

Kwak, E. E. (2007). Effect of rhythmic auditory stimulation on gait performance in children with spastic cerebral palsy. Journal of Music Therapy. https://doi.org/10.1093/jmt/44.3.198.

Moleong, L.J. (2011). Metodologi Penelitian Kualitatif Edisi Revisi. Bandung: PT. Remaja Rosdakarya.

Rainey Perry, M. M. (2003). Relating Improvisational Music Therapy with Severely and Multiply Disabled Children to Communication Development. Journal of Music Therapy. https://doi.org/10.1093/jmt/40.3.227.

Reschke-Hernández, A. E. (2011). History of music therapy treatment interventions for children with autism. Journal of Music Therapy. https://doi.org/10.1093/jmt/48.2.169.

Rury Soeriawinata, M.Sc., M.Ed., BCBA., (2018). Verbal Behavior dan Applied Analysis membantu Anak Autisme dan ABK Menemukan Fungsi Bahasa. Yogyakarta: Quantum.

Suharto.( 2008). Kamus Musik. Jakarta: Grasindo. 
Syam Fathurrachmanda, dkk., (2013). Implementasi Rencana Program Rehabilitasi Sosial Bagi Penyandang Disabilitas Netra (Studi di UPT Rehabilitasi Sosial Cacat Netra Malang, Jurnal Wacana, 16(4).

Yinger, O. S., \& Gooding, L. (2014). Music therapy and music medicine for children and adolescents. Child and Adolescent Psychiatric Clinics of North America. https://doi.org/10.1016/j.chc.2013.03.003.

Yu, H., Liu, Y., Li, S., \& Ma, X. (2009). Effects of music on anxiety and pain in children with cerebral palsy receiving acupuncture: A randomized controlled trial. International Journal of Nursing Studies. https://doi.org/10.1016/j.ijnurstu.2009.05.007. 